\title{
NEW MODELS TO PREDICT THE VISCOSITY OF EXTRA-HEAVY OIL IN COLOMBIAN FIELDS
}

\author{
NUEVOS MODELOS PARA EL CÁLCULO DE LA VISCOSIDAD DE CRUDOS \\ EXTRAPESADOS EN CAMPOS COLOMBIANOS
}

\author{
Mauricio Pertuz-Parra ${ }^{1 *}$, Gian Pino-Tarazona ${ }^{1}, J$ ohn León-Pabón ${ }^{1}$, Carlos Pérez-Reyes ${ }^{2}$ \\ and Carlos-Andrés Díaz-Prada ${ }^{3}$ \\ 'Universidad Industrial de Santander, Bucaramanga, Santander, Colombia \\ ${ }^{2}$ Corporación Naffrac, Bucaramanga, Santander, Colombia \\ ${ }^{3}$ Ecopetrol S.A. - Instituto Colombiano del Petróleo (ICP), A.A. 4185 Bucaramanga, Santander, Colombia \\ e-mail: mauriciopertuz@hotmail.com
}

(Received: Jan. 31, 2014; Accepted: Jun. 13, 2014)

\begin{abstract}
T iscosity is one of the fundamental properties of fluids in calculating the pressure drop of fluid flow through pipes or porous media. It is also highly relevant in interpreting production tests, hydrocarbon transport and the analysis of problems that may arise in the well. This paper introduces an adjustment to the De Ghetto viscosity model in order to accurately predict the viscosity of undersaturated extra-heavy oil.

The adjustment of the De Ghetto model for undersaturated extra-heavy oil has been developed using a database of PVT analysis of extra-heavy oil to assess the accuracy of the models published in literature. Subsequently, by using statistical analysis and regression techniques, the models with the best approximation to the values of the PVT reports were adjusted, thus resulting in two models with absolute average error rates of 4.69 and $2.42 \%$. These rates are valid for oils with API gravities ranging from 6.5 to 9.5 , in order to accurately predict the viscosity of undersaturated extra-heavy oils.
\end{abstract}

Keywords: Extra-heavy oil, Undersaturated oil, Regression analysis, PVT testing, Viscosity correlations.

How to cite: Pertuz-Parra, M., Pino-Tarazona, G., León-Pabón, J., Pérez-Reyes, C. \& Díaz-Prada, C. A. (2014). New models to predict the viscosity of extra-heavy oil in colombian fields. CT\&F - Ciencia, Tecnología y Futuro, 5(4), 23-34.

*To whom correspondence should be addressed 


\section{RESUMEN}

L

a viscosidad es una de las propiedades fundamentales de los fluidos en el cálculo de la caída de presión del flujo de fluidos a través de las tuberías o los medios porosos; también tiene una gran relevancia en la interpretación de pruebas de producción, en el transporte de los hidrocarburos y en el análisis de problemas que puedan presentarse en el pozo. Este artículo presenta un ajuste del modelo de viscosidad propuesto por De Ghetto, con el fin de estimar de manera más precisa la viscosidad de los crudos extrapesados subsaturados.

El ajuste del modelo de De Ghetto para crudos extrapesados subsaturados se ha desarrollado a partir de una base de datos de análisis PVT de crudos extrapesados, con el propósito de evaluar la precisión de los modelos publicados en la literatura. Posteriormente, mediante el uso de técnicas de regresión y análisis estadístico, se realiza el ajuste de los modelos que tuvieron una mejor aproximación a los valores de los reportes PVT; obteniéndose de esta manera dos modelos con porcentajes de error promedio absoluto del 4.69 y $2.42 \%$, válidos para crudos con gravedades API entre 6.5 a 9.5 , los cuales permiten estimar de forma más precisa la viscosidad de los crudos extrapesados subsaturados.

Palabras clave: Crudo extrapesado, Crudo subsaturado, Análisis de regresión, Pruebas PVT, Correlaciones de viscosidad.

\section{RESUMO}

\footnotetext{
viscosidade é uma das propriedades fundamentais dos fluídos no cálculo da queda de pressão do Aluxo de fluídos através das tubulações ou dos meios porosos; também tem uma grande relevância - na interpretação de provas de produção, no transporte dos hidrocarbonetos e na análise de problemas que podem ocorrer no poço. Este artigo apresenta um ajuste do modelo de viscosidade proposto por De Ghetto, com a finalidade de estimar de maneira mais precisa a viscosidade dos crus extra pesados subsaturados.
}

O ajuste do modelo de De Ghetto para crus extra pesados subsaturados foi desenvolvido a partir de uma base de dados de análises PVT de crus extra pesados, com o propósito de avaliar a precisão dos modelos publicados na literatura. Posteriormente, mediante o uso de técnicas de regressão e de análise estatística, foi realizado o ajuste dos modelos que tiveram uma melhor aproximação aos valores dos relatórios PVT; foram obtidos desta maneira dois modelos com porcentagens de erro médio absoluto de 4.69 e 2.42\%, válidos para crus com gravidades API entre 6.5 a 9.5; os quais permitem estimar de forma mais precisa a viscosidade dos crus extra pesados subsaturados.

Palavras-chave: Cru extra pesado, Cru subsaturado, Análise de regressão, Provas PVT, Correlações de viscosidade. 


\section{INTRODUCTION}

In many places in the world, the industry's attention is moving towards the development of heavy and extra-heavy oils, which represent $65 \%$ of the world's reserves (Treviño, 2006). Such is the case of the San Fernando formation in Colombia, the Orinoco belt in Venezuela, and heavy and extra-heavy oil production areas in California, Canada, Mexico and other places in the world.

The development strategies of an oil field require knowledge of the physical properties of the fluid. Furthermore, viscosity plays an important role in interpreting production tests, hydrocarbon transport and the analysis of problems that may arise during the productive life of the field. Ideally, these properties are determined by laboratory testing. However, the experimental data are not always available and empirical correlations have to be used to determine the values required at different pressure and temperature conditions (Ahmed, 2007).

The variety of models to predict viscosity in different types of oil in the world is wide, but with regard to extra-heavy oil, there are just a few.

Based on PVT test reports from different extraheavy oil fields, and in the use of statistical analysis and regression techniques, this paper proposes an adjustment to the most reliable model published in literature to predict the viscosity of live oil so that its behavior is more accurate when it comes to predicting this property in undersaturated extra-heavy oil.

\section{THEORETICAL FRAMEWORK}

The models developed in the literature to predict the viscosity of undersaturated oils have demonstrated that viscosity increases proportionally at the rate of pressure. In general, these models correlate undersaturated oil viscosity in terms of the increase in pressure with respect to bubble pressure and viscosity at bubble point. Mathematically, it can be expressed as follows: $\mu_{o u}=f\left(\mu_{o u}, \Delta P\right)$

The following are the main models reported in the literature to predict the viscosity of undersaturated oils based on experimental data. All these models assume Newtonian behavior of undersaturated fluids at calculation temperatures and pressures.

Vásquez and Beggs (1980) presented the development of an undersaturated oil viscosity model based on the use of parameters that are commonly found in PVT reports. The database used consisted of 3593 points of undersaturated oils ranging from 15 to 60 API.

The undersaturated oil viscosity model created by Kartoatmodjo and Schmidt (1991) is based on the proposal developed by Standing (1947), using non-linear regression techniques with 3588 viscosity data from 321 PVT reports of undersaturated heavy oils (14 - 59 API). The new model reported an average absolute error of $2.64 \%$.

In the development of their viscosity model, Petrosky and Farshad (1995) used samples of undersaturated oil from the Gulf of Mexico (25 - 46 API); the authors reported average relative and absolute errors between -0.2 and $2.9 \%$ respectively, with a standard deviation of 4.2 .

The first viscosity model for extra-heavy oil was created by De Ghetto, Paone and Villa (1995). The model was developed based on a non-linear regression analysis, which takes into account properties such as API gravity and dead oil viscosity for the prediction. The new equations have an average absolute error of $6 \%$ and were developed for oils between 7 and 9.9 API.

Elsharkawy and Alikhan (1999) presented a model to predict the viscosity of undersaturated oils, by using a database created with 145 viscosity points for undersaturated oils between 12 and 22 API from the Middle East.

The undersaturated oil viscosity model proposed by Hossain et al. (2005) was obtained based on a non-linear regression analysis carried out on 39 viscosity data of undersaturated heavy oils (15 - 21 API). 
Finally, Bergman and Sutton (2006) proposed a new model to predict the viscosity of undersaturated oils, designed particularly for oil in extreme conditions (Deep Water) based on a data base of 454 oil samples from around the world, ranging from 15 to $48 \mathrm{API}$.

\section{DEVELOPMENT OF THE MODEL}

The adjustment process for the undersaturated oil viscosity model was carried out in the first instance by means of a validation and discretization of the viscosity data from the PVT reports. This was done to detect any deficiencies and verify that they belonged to extra- heavy oil, thus avoiding shortcomings in the predictive capacity of the different models that were modified.

In second place, by selecting the papers that are mostly used in the industry to predict the viscosity of undersaturated oils, a comparative analysis was conducted to select the model with the best prediction with respect to the experimental viscosity information in the PVT reports.

The best model was selected based on statistical analysis, taking Relative Error $\left(E_{r}\right)$ as a starting point and taking into account the model with the lowest Average Absolute Error $\left(E_{a p}\right)$ as the first criterion of selection.

The statistical measurements were obtained as follows:

$E_{r}=\left(\frac{Y_{\text {est }}-Y_{\text {exp }}}{Y_{\text {exp }}}\right) * 100$

$E_{a p}=\frac{1}{n} * \sum_{i=1}^{n}\left|E_{r}\right|_{i}$

In the case that similar $E_{a p}$ values are generated, the model with the lowest Standard Deviation $(\sigma)$ is used as the second criterion of selection. This was obtained using the following expression:

$\sigma=\sqrt{\frac{\sum\left(Y_{\text {est }}-Y_{\text {exp }}\right)^{2}}{n-1}}$
The adjusted model was obtained based on the optimization for each point of the model selected during the selection stage, followed by a regression analysis using the trial license of the TableCurve2 $\mathrm{D}^{\circledR}$ statistical program.

Finally, taking an average absolute error of up to $5 \%$ as a point of reference for the measurement of viscosity data to be considered acceptable, the adjusted models were subjected to statistical analysis to observe predictive capacity and compared once again with the initial models.

\section{RESULTS}

Initially in this paper, there was PVT testing information from 14 heavy oil production wells, with a total of 16 points to analyze (see Table 1); some from the San Fernando Formation in Colombia and others taken from databases in the literature of similar samples of extra-heavy oil.

The oils analyzed, as illustrated in Table 1, had API gravities ranging from 6.5 to 9.5 , and dead oil viscosities ranging from 160.7 and $1157.44 \mathrm{cP}$.

The models of De Ghetto, Kartoatmodjo, Petrosky, Hossain, Vásquez and Beggs, Bergman and Sutton and Elsharkawy were selected to carry out the initial comparative analysis in which the parameters required for each model were calculated, followed by the prediction of the undersaturated oil viscosity $\left(\mu_{o s}\right)$ in each case, and based on the information obtained by PVT testing.

The range of validity defined by each author for these models is listed in Table 2.

The model proposed by De Ghetto had the best performance with an average absolute error of $7.12 \%$, as illustrated in Figure 1. This leads to the conclusion that this is the best model to make the adjustment to predict the viscosity of undersaturated extra-heavy oils. You can see that the other models had high error percentages, as they were operating outside the permissible ranges 
Table 1. Relevant information of the PVT reports to make the adjustment.

\begin{tabular}{|ccccccccc|}
\hline Data & API & Temperature & Pressure & $\begin{array}{c}\text { Bubble } \\
\text { Pressure } \\
\left(\mathbf{P b}_{\mathrm{b}}\right)\end{array}$ & $\begin{array}{c}\text { Viscosity at } \\
\text { Bubble Point } \\
\left(\mu_{\mathrm{ob}}\right)\end{array}$ & $\begin{array}{c}\text { Dead Oil } \\
\text { Viscosity } \\
\left(\mu_{\mathrm{od}}\right)\end{array}$ & $\begin{array}{c}\text { Undersaturated } \\
\text { Oil Viscosity } \\
\left(\mu_{\mathrm{ou}}\right)\end{array}$ \\
\hline 1 & 6.50 & 99.000 & 4808.081 & 697.641 & 83.500 & 230.000 & cP \\
\hline 2 & 7.30 & 105.380 & 4732.666 & 249.472 & 177.400 & 211.000 & 348.000 \\
\hline 3 & 7.85 & 84.444 & 3315.000 & 586.000 & 299.000 & 1157.440 & 772.000 \\
\hline 4 & 7.85 & 84.444 & 3015.000 & 586.000 & 299.000 & 1157.440 & 720.000 \\
\hline 5 & 7.85 & 84.444 & 2015.000 & 586.000 & 299.000 & 1157.440 & 547.000 \\
\hline 6 & 7.85 & 84.444 & 1015.000 & 586.000 & 299.000 & 1157.440 & 374.000 \\
\hline 7 & 7.85 & 84.444 & 715.000 & 586.000 & 299.000 & 1157.440 & 322.000 \\
\hline 8 & 7.90 & 98.278 & 4148.145 & 342.299 & 151.800 & 236.000 & 269.500 \\
\hline 9 & 8.00 & 102.000 & 4494.792 & 619.326 & 240.000 & 264.900 & 307.300 \\
\hline 10 & 8.00 & 99.000 & 4708.009 & 668.634 & 118.000 & 230.000 & 205.500 \\
\hline 11 & 8.30 & 100.000 & 4883.504 & 639.637 & 116.300 & 262.000 & 190.100 \\
\hline 12 & 8.60 & 103.000 & 4996.635 & 626.576 & 85.600 & 186.000 & 163.800 \\
\hline 13 & 8.90 & 100.000 & 4908.156 & 597.562 & 106.500 & 219.200 & 192.000 \\
\hline 14 & 9.00 & 98.889 & 4808.081 & 654.133 & 72.700 & 160.700 & 125.100 \\
\hline 15 & 9.50 & 82.778 & 2015.000 & 600.000 & 450.000 & 818.000 & 535.000 \\
\hline 16 & 9.50 & 82.778 & 2515.000 & 600.000 & 450.000 & 818.000 & 559.000 \\
\hline
\end{tabular}

Table 2. Ranges defined by authors for undersaturated oil models.

\begin{tabular}{|lccc|c|c|c|c|}
\hline \multicolumn{7}{|c|}{ Models } \\
& De Ghetto & Kartoatmodjo & Petrosky & Hossain & Vásquez & Elsharkawy & Bergman \\
\hline No. Data & 63 & 5321 & 404 & 263 & 3143 & 254 & 454 \\
\hline $\mathrm{API}$ & $7.1-9.9$ & $14.4-58.95$ & $25.4-46.1$ & $15-21$ & $15.3-59.5$ & $12.3-22.1$ & $15-45$ \\
\hline $\mathrm{T}\left({ }^{\circ} \mathrm{C}\right)$ & $55-121.1$ & $26-160$ & - & $51-93.3$ & - & - & - \\
\hline $\mathrm{Rs}(\mathrm{scf} / \mathrm{STB})$ & $17.2-640$ & $2.3-572$ & $21-1885$ & $19-493$ & - & $10-3600$ & - \\
\hline $\mathrm{Pb}(\mathrm{Psia})$ & $209-4022$ & - & - & $222-1458$ & - & - & - \\
\hline$\mu_{\mathrm{os}}(\mathrm{CP})$ & $2.1-296$ & - & - & $3.6-360$ & - & $0.05-20.8$ & - \\
\hline$\mu_{\mathrm{ou}}(\mathrm{cP})$ & $0.224-4.1$ & $0.096-586$ & $0.22-4.1$ & - & - & - & $0.2-5.7$ \\
\hline $\mathrm{E}_{\mathrm{rp}}(\%)$ & - & - & - & - & - & 2.8 & - \\
\hline $\mathrm{E}_{\mathrm{op}}(\%)$ & 4.0 & 6.87 & 2.9 & 20.1 & 7.4 & 12.1 & 7.3 \\
\hline
\end{tabular}


of validity for each of them. Although this behavior was somewhat predictable, the decision was made to take these models into account for the present analysis because occasionally, an extrapolated model can have good behavior with respect to the data analyzed. In addition, the information available for other extra-heavy oils exclusive models is very scarce (except for the De Ghetto model).

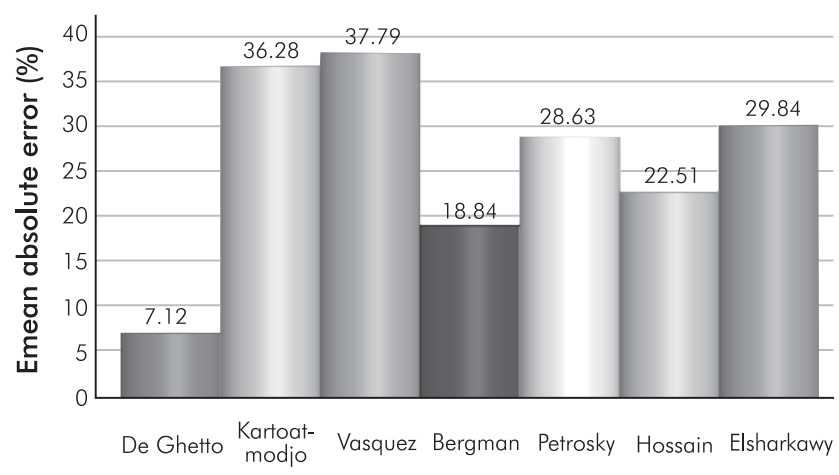

Figure 1. Initial comparative analysis for the undersaturated crude oil viscosity models.

\section{Adjustment of the Selected Model}

The model proposed by De Ghetto to predict the viscosity of extra-heavy oils was the one that came closest to the viscosity data obtained by PVT testing. Therefore, in the selection stage, it was selected as the best one to make the adjustment. This model is based on the premise proposed by Labedi (1992) in the creation of his viscosity model for undersaturated oil, which in turn is based on the existence of a linear relationship between the viscosity of undersaturated oil $\left(\mu_{o u}\right)$ and pressure over bubble point (P). De Ghetto expresses the above premise as follows:

$$
\begin{aligned}
& \mu_{o u}=\mu_{o b}-\left(1-\frac{P}{P_{b}}\right) M_{\mu} \\
& M_{\mu}=\left(\frac{X * Y}{Z}\right) \\
& \mathrm{X}=10^{-2.19}\left(\mu_{o d}^{1.055}\right) \\
& \mathrm{Y}=\left(P_{b}^{0.3132}\right)
\end{aligned}
$$

$\mathrm{Z}=10^{0.0099 * A P I}$

The first step in adjusting the De Ghetto model was finding the optimal " $m$ " and " $M_{\mu}$ " slopes for each of the viscosity data reported in the PVT tests. The values were found directly with the equation of the line that describes each of the points of the PVT tests, and analyzed as illustrated below:

$$
\begin{aligned}
& m=\frac{\mu_{o u}-\mu_{o b}}{P-P_{b}} \\
& M_{\mu}=m * P_{b}
\end{aligned}
$$

At the second stage of the adjustment process, the square of the difference between optimal $M_{\mu}$ and $M_{\mu}{ }^{*}$, calculated using the De Ghetto model, was determined for each of the data of the PVT report. In addition, the De Ghetto model was optimized for each point, by using the statistical program as illustrated in Table 3.

After completing the process, the optimal values of the terms $\mathrm{X}, \mathrm{Y}$ and $\mathrm{Z}$ were estimated, using the information from the PVT reports. Three regression analyses were carried out with the values of terms X, $\mathrm{Y}$ and $\mathrm{Z}$-before and after optimization- and by using TableCurve2 $\mathrm{D}^{\circledR}$ to find the best fit in the coefficients of the model proposed by De Ghetto. The methodology used for the regression analyses can be summarized as follows:

- In Cartesian coordinates, plot the optimal values of $\mathrm{X}, \mathrm{Y}$ and $\mathrm{Z}$ vs. the values of $\mu_{o d}, P_{b}$ and API.

- Once the data dispersion is found, enter the equations corresponding to each of the terms in the statistical package.

- Adjust each equation.

- Once the program has made the adjustment, verify that the statistical parameters are within the desired expectations.

The regression curves relating to the analyses are listed below in Figures 2, 3 and 4. The summary of the statistical information for each regression analysis is 
Table 3. Results of the process of optimizing the model proposed by De Ghetto.

\begin{tabular}{|c|c|c|c|c|c|c|c|}
\hline \multirow{2}{*}{ Data } & \multirow{2}{*}{$M_{\mu}$} & \multicolumn{6}{|c|}{ Optimization } \\
\hline & & $a$ & b & c & d & $M_{\mu}^{*}$ & $\left(M_{\mu}-M_{\mu}^{*}\right)^{2}$ \\
\hline 1 & 12.6400 & 2.1596 & 1.0323 & 0.3122 & 0.0099 & 12.6444 & $3.16 \mathrm{E}-30$ \\
\hline 2 & 9.3700 & 2.1513 & 1.0513 & 0.3137 & 0.0099 & 9.3707 & $7.89 E-29$ \\
\hline 3 & 101.5700 & 2.1349 & 1.0916 & 0.3162 & 0.0098 & 101.5676 & $0.00 E+00$ \\
\hline 4 & 101.5700 & 2.1349 & 1.0916 & 0.3162 & 0.0098 & 101.5669 & $5.05 \mathrm{E}-27$ \\
\hline 5 & 101.7000 & 2.1347 & 1.0917 & 0.3162 & 0.0098 & 101.6991 & $1.29 E-26$ \\
\hline 6 & 102.4500 & 2.1338 & 1.0924 & 0.3163 & 0.0098 & 102.4476 & $3.23 \mathrm{E}-27$ \\
\hline 7 & 104.4800 & 2.1315 & 1.0943 & 0.3164 & 0.0098 & 104.4806 & $5.05 E-27$ \\
\hline 8 & 10.5900 & 1.1183 & 0.6084 & 0.3067 & 0.0098 & 10.5857 & $3.16 \mathrm{E}-30$ \\
\hline 9 & 10.7500 & 2.2387 & 1.0249 & 0.3102 & 0.0099 & 10.7549 & $8.68 \mathrm{E}-11$ \\
\hline 10 & 14.4800 & 2.1547 & 1.0614 & 0.3143 & 0.0099 & 14.4837 & $1.55 \mathrm{E}-28$ \\
\hline 11 & 11.1200 & 2.2305 & 1.0285 & 0.3106 & 0.0099 & 11.1230 & $5.05 E-29$ \\
\hline 12 & 11.2100 & 2.1555 & 1.0623 & 0.3144 & 0.0099 & 11.2122 & 7.89E-29 \\
\hline 13 & 11.8500 & 1.5486 & 0.7906 & 0.3096 & 0.0098 & 11.8525 & $3.16 \mathrm{E}-30$ \\
\hline 14 & 8.2500 & 2.1103 & 0.9924 & 0.3134 & 0.0099 & 8.2521 & $1.46 \mathrm{E}-05$ \\
\hline 15 & 36.0400 & 2.0634 & 0.9684 & 0.3132 & 0.0099 & 36.0386 & $3.19 E-05$ \\
\hline 16 & 34.1500 & 2.0685 & 0.9951 & 0.3121 & 0.0099 & 34.1458 & $3.70 \mathrm{E}-07$ \\
\hline
\end{tabular}

listed in Table 4. Although the results of the regression analysis are very accurate, it was observed (Figure 2) that for dead oil viscosity values near $800 \mathrm{cP}$, the regression model has certain deficiencies. For this reason, a new function has been sought using TableCurve $2 \mathrm{D}^{\circledR}$ that will adjust more precisely to the values of $\mathrm{X}$. The following function was selected:

$X_{N F}=\frac{1}{a+b *\left[\ln \left(\mu_{o d}\right)\right]^{2}}$

The diagram of the behavior and the information from the regression analysis conducted with this function are illustrated in Figure 5.

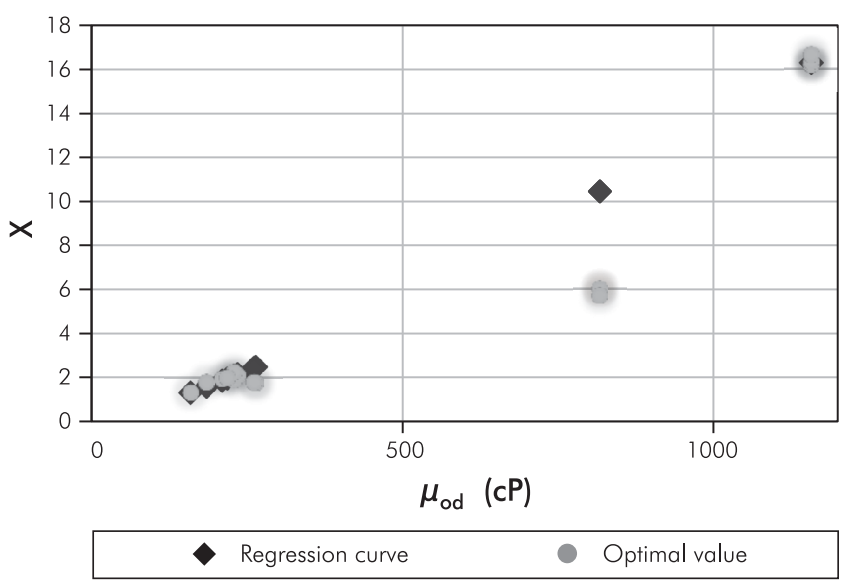

Figure 2. Regression curve for analysis of $X$. 


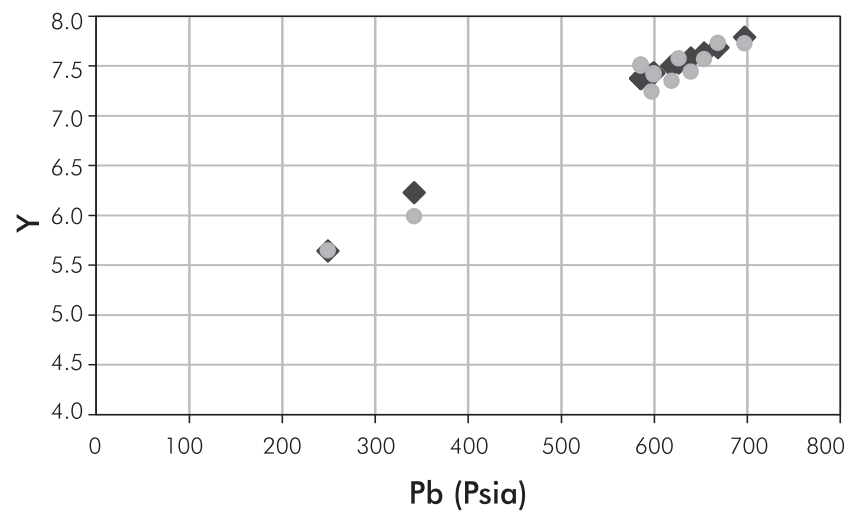

Regression curve Optimal value

Figure 3. Regression curve for analysis of $\mathrm{Y}$.

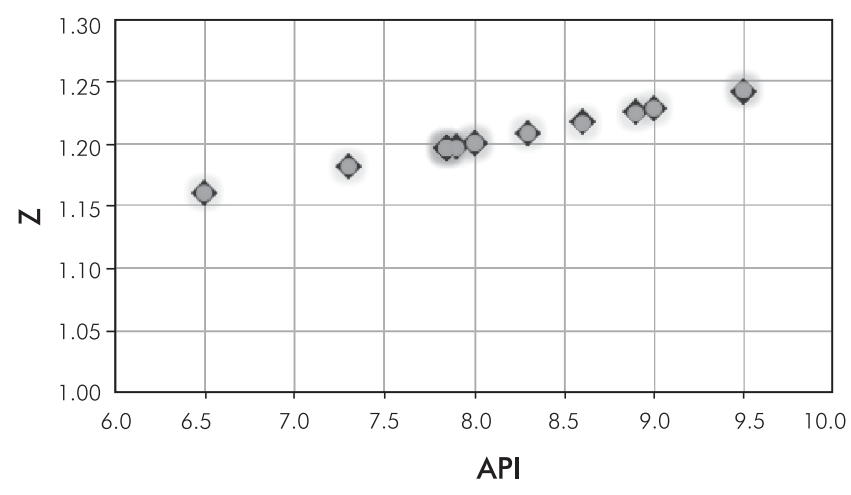

Regression curve

Optimal value

Figure 4. Regression curve for analysis of $Z$.

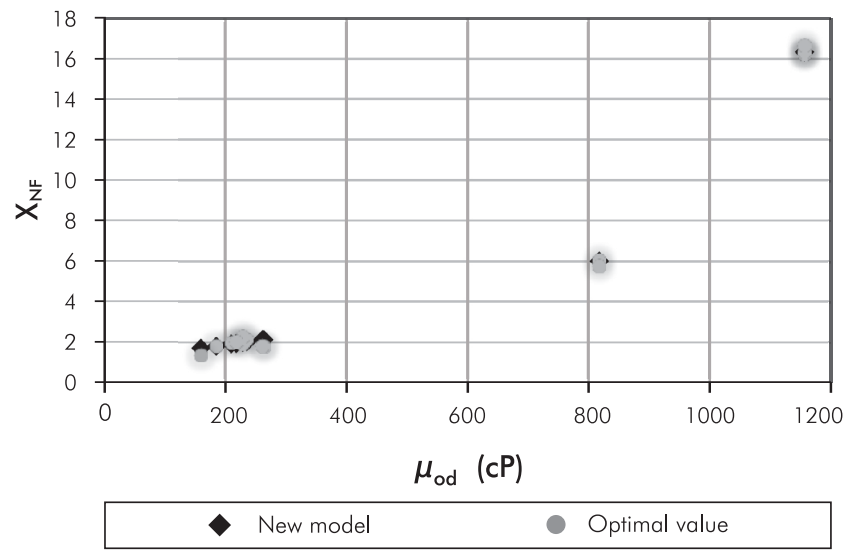

Figure 5. Regression curve for analysis of $X_{N F}$.
Table 4. Statistical analysis obtained from regressions for $X, X_{N F}, Y$ and $Z$.

\begin{tabular}{|c|c|c|c|c|}
\hline \multirow{2}{*}{$\begin{array}{c}\text { Statistical } \\
\text { Analysis }\end{array}$} & \multicolumn{4}{|c|}{ Term } \\
\hline & $X$ & $X_{N F}$ & $Y$ & Z \\
\hline $\begin{array}{c}\text { Determination } \\
\text { Coefficient } \\
\left(R^{2}\right)\end{array}$ & 0.933 & 0.9992 & 0.955 & 0.9998 \\
\hline $\begin{array}{c}\text { Ajusted } \\
\text { Determination } \\
\text { Coefficient } \\
\left(R_{\text {adi }}^{2}\right)\end{array}$ & 0.922 & 0.9990 & 0.952 & 0.9998 \\
\hline $\begin{array}{c}\text { Standard } \\
\text { Deviation } \\
(\sigma)\end{array}$ & 1.812 & 0.2016 & 0.124 & 0.0002 \\
\hline
\end{tabular}

\section{Adjusted De Ghetto Model}

Finally, based on the results of the regression analysis, the De Ghetto model is reformulated with the new coefficients. The adjusted model has been presented as follows:

$\mu_{o u}=\mu_{o b}-\left(1-\frac{P}{P_{b}}\right) M_{\mu}$

$M_{\mu}=\left(\frac{10^{-2.691}\left(\mu_{o d}^{1.274}\right)\left(P_{b}^{0.3134}\right)}{10^{0.00989 * A P I}}\right)$

\section{New Proposed Model}

The model presented based on the correction made for the dead oil viscosity values is presented as follows:

$\mu_{o u}=\mu_{o b}-\left(1-\frac{P}{P_{b}}\right) M_{\mu}$

$M_{\mu}=\left(\frac{\mathrm{X}_{N F} *\left(P_{b}^{0.3134}\right)}{10^{0.00989 * A P I}}\right)$ 


$$
\mathrm{X}_{N F}=\frac{1}{1.1659-0.0222 *\left[\left(\ln \mu_{o d}\right)\right]^{2}}
$$

\section{Evaluation of the Predictive Capacity of the Models}

Figures 6 and 7 are part of a comparative analysis of the adjusted models in this article with the four models that initially had a better fit, including the original model proposed by De Ghetto. This was done to observe the results obtained in the process of adjusting the model for undersaturated extra-heavy oils.

The comparative analysis shows that the percentage of the average absolute error was reduced to $4.69 \%$ with the Adjusted Model of De Ghetto, and in the New Proposed Model, it was reduced to $2.42 \%$. Upon analysis, with respect to the original De Ghetto model (7.12\%), there was an improvement of 2.43 and $4.7 \%$ respectively. These models, like the others proposed for undersaturated oil viscosities, are below the maximum error considered acceptable for a viscosity prediction method, which is approximately $5 \%$.

Finally, Figure 7 shows the unitary tendency line, which represents a perfect scenario where the value calculated with the models is equal to the value measured in the PVT tests and serves as a reference to analyze the results obtained in the adjustment. The improvement obtained in predicting viscosity with the proposal of the new model is significant enough, achieving an improved adjustment of all the data, including intermediate viscosity values $(500 \mathrm{cP})$.

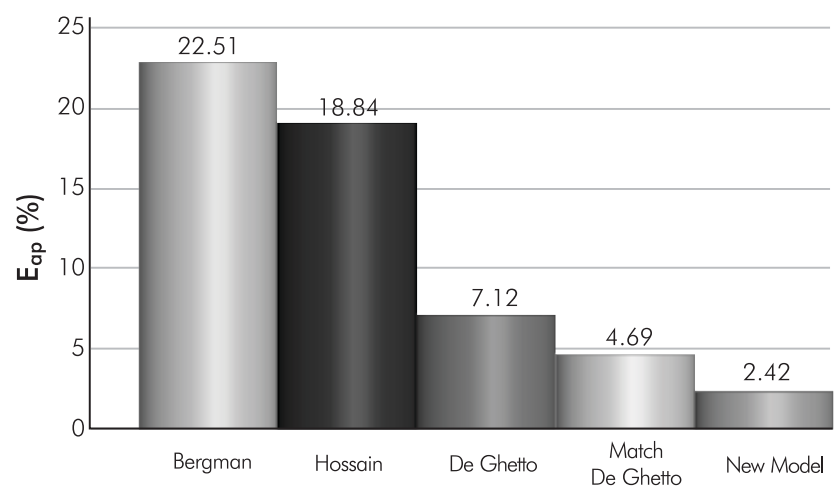

Figure 6. Final comparative analyses for undersaturated oil viscosity models. The image has the same error that the values do not show.

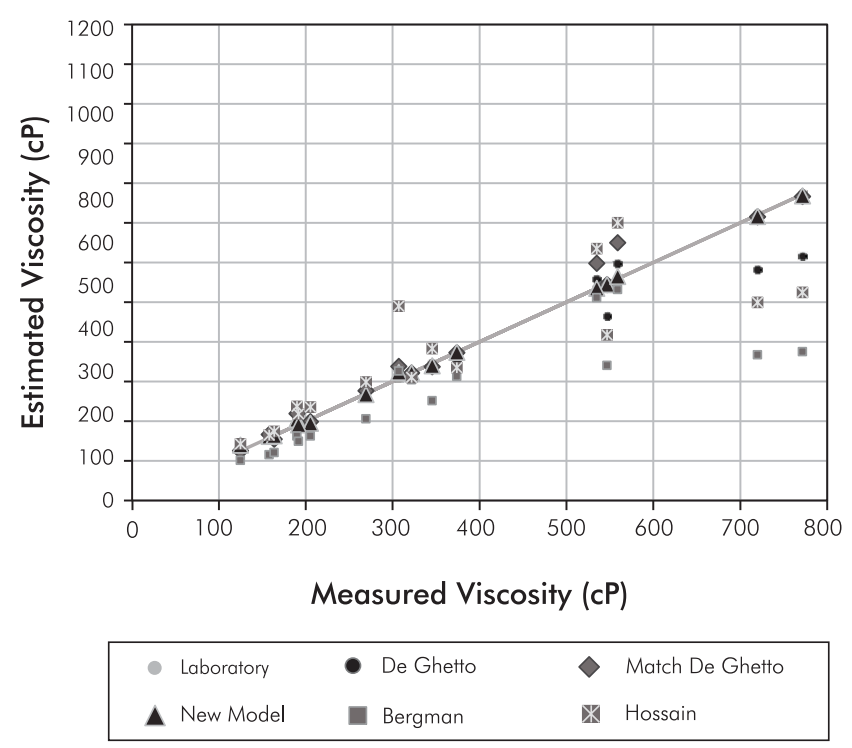

Figure 7. Prediction of undersaturated oil viscosity with the best models.

\section{DISCUSSION}

For a more general validation of the results obtained on the analysis conducted earlier, we decided to test the new equations proposed for undersaturated oil, by using a new group of data from extra-heavy oils obtained from PVT reports of Colombian fields.

A comparative analysis was carried out to observe the behavior of the models proposed for undersaturated extra-heavy oils in the validation process. The results of the comparative analysis are illustrated in Figures 8 and 9 below.

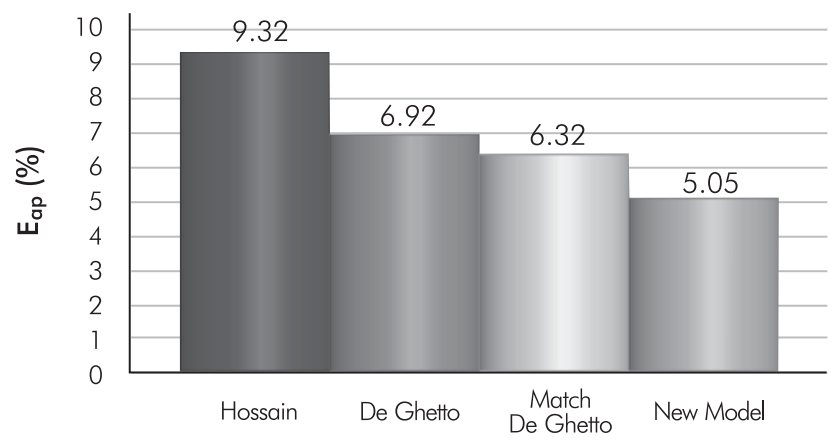

Figure 8. Comparative analysis for the validation of undersaturated oil models. 


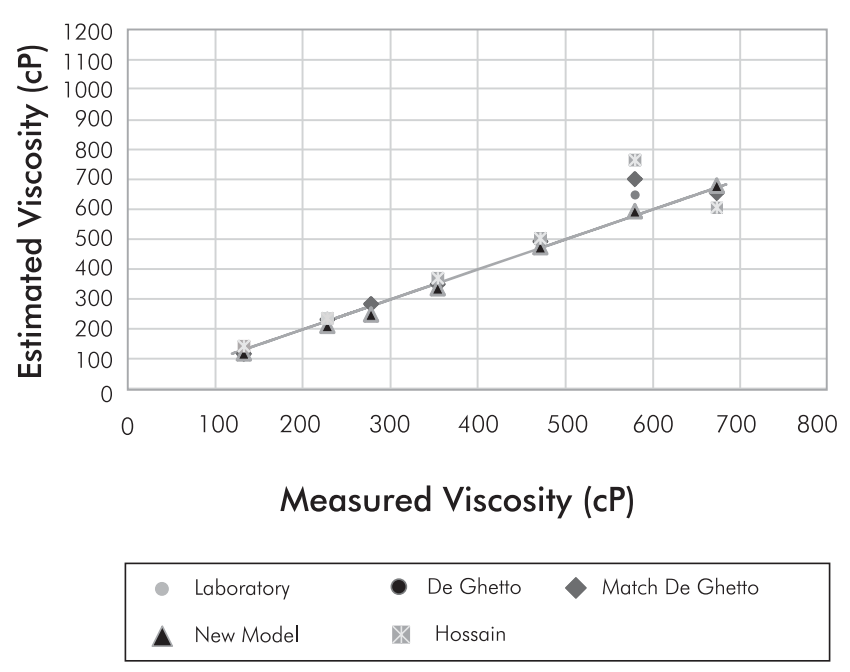

Figure 9. Prediction of undersaturated crude oil viscosity in the validation process.

Figure 8 shows that the behavior of the models follows the same trend as the analysis conducted for the adjustment process, in which the New Proposed Model shows a lower average absolute error (5.05\%) followed by the Modified De Ghetto Model (6.32\%). Again,
Figure 9 confirms the accuracy of the new models to predict viscosity values in the different ranges that were analyzed.

\section{Ranges of Validity of the Proposed Models}

In the case of the models proposed for undersaturated extra-heavy oils, the decrease in the average absolute error is primarily due to the fact that they take into account properties that other models do not correlate, such as Dead Oil Viscosity $\left(\mu_{o d}\right)$ and API gravity. It can be concluded that these properties, along with pressure and viscosity at bubble conditions, are of vital importance to predict viscosity in this type of oils, where $\mu_{o d}$ is the variable that most affects the models to predict this property. Therefore, the $\mu_{o d}$ data entered in the models should be within the ranges used for the development of the proposed models.

Table 5 presents the variables that have been correlated in the new proposed models to predict the viscosity of undersaturated extra-heavy oil, the ranges used to develop them, and the statistical parameters reported in the adjustment process.

Table 5. Validity ranges for the new models.

\begin{tabular}{|cccc|}
\hline \multicolumn{5}{c}{$\begin{array}{c}\text { Models for } \\
\text { Undersaturated Oils }\end{array}$} \\
& $\begin{array}{c}\text { Modified } \\
\text { De Ghetto }\end{array}$ & New Model & De Ghetto \\
No. Data & 16 & 16 & 16 \\
\hline $\mathrm{API}$ & $6.5-9.5$ & $6.5-9.5$ & $6.5-9.5$ \\
\hline$T\left({ }^{\circ} \mathrm{C}\right)$ & $82.7-105.5$ & $82.7-105.5$ & $82.7-105.5$ \\
\hline $\mathrm{P}_{\mathrm{b}}(\mathrm{Psia})$ & $249-698$ & $249-698$ & $249-698$ \\
\hline $\mathrm{P}(\mathrm{Psia})$ & $4996-715$ & $4996-715$ & $4996-715$ \\
\hline $\mathrm{R}_{\mathrm{s}}(\mathrm{scf} / \mathrm{STB})$ & $17.3-208.5$ & $17.3-208.5$ & $17,2-640$ \\
\hline$\mu_{\mathrm{od}}(\mathrm{cP})$ & $160.7-1157.4$ & $160.7-1157.4$ & $160.7-1157.4$ \\
\hline$\mu_{\mathrm{ob}}(\mathrm{cP})$ & $450-72.7$ & $450-72.7$ & $450-72.7$ \\
\hline$\mu_{\mathrm{ou}}(\mathrm{cP})$ & $125-772$ & $125-772$ & $125-772$ \\
\hline $\mathrm{E}_{\mathrm{rp}}(\%)$ & 2.78 & 0.11 & -2.81 \\
\hline $\mathrm{E}_{\mathrm{ap}}(\%)$ & 4.69 & 2.42 & 6.12 \\
\hline$\sigma$ & 30.8 & 2.66 & \\
\hline & & & 6.6 \\
\hline
\end{tabular}




\section{CONCLUSIONS}

- The review of the undersaturated oil viscosity models in literature shows that, in the case of extraheavy oils, the models to predict this property are scarce. This paper discusses two models based on a database created using samples of undersaturated extra-heavy oils, which are applicable for extraheavy oils with API gravities between $6.5^{\circ}$ and $9.5^{\circ}$. The model proposed by De Ghetto was closest to the real data with an average absolute error of $7.12 \%$. Therefore, it was selected as the best one to carry out an adjustment with respect to the database that was created.

- Based on the De Ghetto model, the new models proposed herein were developed using regression techniques, obtaining lower errors in correlation to the maximum permissible error for viscosity models (5\%). In particular, the Modified De Ghetto model and the new model proposed for undersaturated oils showed an average absolute error of 4.6 and $2.42 \%$ in correlation of viscosities, respectively.

- Additional research has been conducted on the modified models based on the new set of extra-heavy oil PVT reports. The models proposed continue to present greater prevision to predict extra-heavy crude oil viscosity, which indicates that the validation process has been satisfactory, thus guaranteeing greater reliability of the proposed models within their respective ranges of validity.

\section{ACKNOWLEDGEMENTS}

The authors would like to thank the School of Petroleum Engineering at Universidad Industrial de Santander (UIS) and Ecopetrol S. A. - Instituto Colombiano del Petróleo (ICP) for providinwg the laboratory information necessary to conduct this research. They would also like to thank the reviewers of this paper for their corrections and suggestions.

\section{REFERENCES}

Ahmed, T. (2007). Equations of state and PVT analysis: Applications for improved reservoir modeling. Houston: Gulf Publishing Company.

Bergman, D. F. \& Sutton, R. P. (2006). Undersaturated oil visco-sity correlation for adverse conditions. SPE Annual Technical Conference and Exhibition, San Antonio. SPE 103144.

De Ghetto, G., Paone, F. \& Villa, M. (1995). Pressure-VolumeTemperature correlations for heavy and extra heavy oils. International Heavy Oil Symposium, Calgary. SPE 30316.

Elsharkawy, A. M. \& Alikhan, A. A. (1999). Models for predicting the viscosity of middle east crude oils. Fuel, 78(8), 891-903.

Hossain, M. S., Sarica, C., Zhang, H. Q., Rhyne, L. \& Greenhill, K. (2005). Assessment wand development of heavy-oil viscosity correlations. SPE International Thermal Operations and Heavy Oil Symposium. Calgary. SPE 97907.

Kartoatmodjo, T. \& Schmidt, Z. (1991). New correlations for crude oil physical properties. SPE 23556.

Labedi, R. (1992). Improved correlations for predicting the viscosity of light crudes. J. Petrol. Sci. Eng., 8(3), 221-234.

Petrosky, G. E. \& Farshad, F. F. (1995). Viscosity correlations for Gulf of México crude oils. SPE Production Operation Symposium, Oklahoma. SPE 29468.

Standing, M. B. (1947). A Pressure Volume-Temperature correlation for mixtures of California oils and gases. Drilling and Production Practices, New York. API 47-275.

Treviño, M. (2006). Futuro pesado. Carta Petrolera. 114.

Vásquez, M. E. \& Beggs, H. D. (1980). Correlation for fluid physical property prediction. J. Petrol. Technol., 32(6), 968-970.

\section{AUTHORS}

Mauricio Javier Pertuz Parra

Affiliation: Universidad Industrial de Santander

Petroleum Engineer, Universidad Industrial de Santander e-mail: mauriciopertuz@hotmail.com 


\section{Gian Carlo Pino Tarazona}

Affiliation: Universidad Industrial de Santander Petroleum Engineer, Universidad Industrial de Santander e-mail: giank71@hotmail.com

\section{John Alexander León Pabón}

Affiliation: Universidad Industrial de Santander

Petroleum Engineer, Universidad Industrial de Santander

M. Sc. in Engineering Hydrocarbons. Universidad Industrial de Santander

e-mail: John.leon@correo.uis.edu.co

\section{Carlos Andrés Pérez Reyes}

Affiliation: Corporación Natfrac

Chemical Engineer, Universidad Industrial de Santander

e-mail: carlos.perez@Natfrac.com

\section{Carlos Andrés Díaz Prada}

Affiliation: Ecopetrol S.A.

Petroleum Engineer, Universidad Industrial de Santander M. Sc. in Engineering Hydrocarbons, Universidad Industrial de Santander

e-mail: carlosan.prada@ecopetrol.com.co

\section{NOTATION}

$\begin{array}{ll}\text { API } & \text { API Gravity } \\ \mathrm{T} & \text { Temperature, }{ }^{\circ} \mathrm{C} \\ \mathrm{P}_{\mathrm{b}} & \text { Bubble Pressure, Psia } \\ \mathrm{P} & \text { Pressure, Psia } \\ \mu_{\mathrm{od}} & \text { Dead Oil Viscosity, cP } \\ \mu_{\mathrm{ob}} & \text { Dead Oil Viscosity at Bubble Point, cP } \\ \mu_{\mathrm{ou}} & \text { Undersaturated Oil Viscosity, cP } \\ \mathrm{X}_{\mathrm{NF}} & \mathrm{X} \text { with the new function } \\ \mathrm{n} & \text { Number of data analyzed } \\ \mathrm{Y}_{\text {est }} & \text { Estimated Value } \\ \mathrm{Y}_{\text {exp }} & \text { Experimental Value } \\ \mathrm{R}^{2} & \text { Determination Coefficient } \\ \mathrm{R}_{\text {adj }}{ }_{2} & \text { Adjusted Determination Coefficient } \\ \mathrm{E}_{\mathrm{r}} & \text { Relative Error } \\ \mathrm{E}_{\mathrm{rp}} & \text { Average Relative Error, } \% \\ \mathrm{E}_{\mathrm{ap}} & \text { Average Absolute Error, \% } \\ \sigma & \text { Standard Deviation }\end{array}$

